\title{
Gambaran pemberian makanan pendamping ASi anak usia 6-24 bulan di Desa Mopusi Kecamatan Lolayan Kabupaten Bolaang Mongondow Induk
}

\author{
${ }^{1}$ Olivia Mangkat \\ ${ }^{2}$ Nelly Mayulu \\ ${ }^{2}$ Shirley E. S. Kawengian
}

\author{
${ }^{1}$ Kandidat Skripsi Fakultas Kedokteran Universitas Sam Ratulangi Manado \\ ${ }^{2}$ Bagian Ilmu Gizi Fakultas Kedokteran Universitas Sam Ratulangi Manado \\ Email: olivia_mangkat@yahoo.com
}

\begin{abstract}
According to Sustainable Development Goals/Millennium Development Goals (SDG's/MDG's), the infant mortality rate is still relatively high due to poor nutrition for pregnant women and infants. The best food for infants aged 0-6 months is breast milk. After 6 months, breast milk will only meet about $60-70 \%$ of the infant's need, while $30-40 \%$ should be achieved from complementary foods. This study was aimed to describe the complementary feeding in Mopusi village, Lolayan, Bolaang Mongondow Induk. This was a descriptive study with a cross sectional design. Respondents were 90 mothers with children aged 6-24 months lived at Mopusi village from September 2014 until December 2014. Data were obtained by using questionnaires, and were analyzed with SPSS. The results showed that 32 infants $(35.6 \%)$ were fed with manufactured complementary food; the most commonly given was formula milk (37.5\%) and the least one was pureed Sun (15.6\%). Of 58 infants $(64.4 \%)$ who were fed with family foods, the most given food was rice (25.9\%) and the least one was meat (3.4\%). Conclusion: In this study, the most complementary food for infants aged 0-6 months was family food, rice.
\end{abstract}

Keywords: breastfeeding, complementary feeding, manufactured, family foods

\begin{abstract}
Abstrak: Angka kematian bayi sesuai SDG's/MDG's (Sustainable Development Goals/Millenium Development Goals) relatif masih cukup tinggi. Penyebabnya antara lain nutrisi yang buruk untuk ibu hamil dan bayi. Makanan terbaik untuk bayi usia 0-6 bulan ialah ASI. Setelah 6 bulan, ASI hanya memenuhi sekitar 60-70\% kebutuhan bayi, sedangkan 30-40\% harus dipenuhi dari makanan pendamping ASI (MP-ASI). Penelitian ini bertujuan untuk mengetahui gambaran pemberian MP-ASI di Desa Mopusi, Kecamatan Lolayan, Kabupaten Bolaang Mongondow Induk. Jenis penelitian ini ialah deskriptif dengan desain potong lintang. Responden ialah ibu yang memiliki bayi usia 6-24 bulan sebanyak 90 orang di Desa Mopusi pada bulan September 2014-Desember 2014. Data diperoleh melalui kuesioner dan dianalisis dengan SPSS. Hasil penelitian memperlihatkan sebanyak 32 bayi $(35,6 \%)$ mendapat MP-ASI pabrikan, yang paling banyak diberikan ialah susu formula $(37,5 \%)$ dan paling sedikit diberikan ialah bubur Sun (15,6\%). Sebanyak 58 bayi $(64,4 \%)$ mengonsumsi MP-ASI lokal, yang paling banyak diberikan ialah nasi $(25,9 \%)$ dan yang paling sedikit diberikan ialah daging (3,4\%). Simpulan: Pada studi ini, jenis MP-ASI yang paling sering diberikan pada bayi usia 6-24 bulan ialah MP-ASI local, yaitu nasi.
\end{abstract}

Kata kunci: ASI, MP-ASI, lokal, pabrikan

Angka kematian bayi sesuai SDG's/MDG's (Sustainable Development Goals/Millenium Development Goals) relatif masih cukup tinggi. Penyebabnya antara lain nutrisi yang buruk untuk ibu hamil dan bayi. Nutrisi merupakan dasar utama 
kelangsungan hidup dan tumbuh kembang anak yang berpengaruh nanti pada masa depannya. ${ }^{1}$

Setiap tahun kurang lebih 130 juta bayi lahir dan kurang lebih 4 juta bayi meninggal pada minggu pertama kelahiran. Kebanyakan dari bayi yang meninggal ini terjadi di negara berkembang. Gizi yang buruk merupakan penyebab kematian pada 3,5 juta anak dan 35\% dari beban pada anak di bawah lima tahun dan $11 \%$ dari ketidaksanggupan dalam mencapai kehidupan (DALY's = Disability Adjusted Life Years). ${ }^{2}$

Pemerintah terus berupaya khususnya dalam menangani masalah gizi balita karena hal ini berpengaruh terhadap pencapaian salah satu tujuan Millennium Development Goals (MDGs) pada Tahun 2014 yaitu mengurangi dua per tiga tingkat kematian anak-anak usia di bawah lima tahun. Prevalensi kekurangan gizi pada anak balita menurun dari $25,8 \%$ pada Tahun 2004 menjadi 18,4 \% pada Tahun 2007, sedangkan Rencana Pembangunan Jangka Menengah Nasional (RPJMN) Tahun 2010-2014 menargetkan penurunan prevalensi kekurangan gizi (gizi kurang dan gizi buruk) pada anak balita adalah $<15,0 \%$ pada Tahun 2014. ${ }^{3,4}$

Kondisi kesehatan masyarakat Sulawesi Utara berdasarkan indikator status gizi Sulawesi Utara mendapatkan gangguan pertumbuhan bayi yang terjadi sejak usia dini (4 bulan) yang ditandai dengan rendahnya berat badan dan tinggi badan. Hal tersebut terutama disebabkan rendahnya status gizi ibu hamil, Perkembangan status gizi Sulawesi utara untuk persentase Sulawesi utara gizi buruk/kurang menurun pada tahun 2010 dibandingkan pada tahun 2007 . $^{4}$

Pemberian makanan yang cukup pada periode awal kehidupan merupakan hal yang vital bagi pertumbuhan dan perkembangan anak. Beberapa penelitian telah membuktikan bahwa pemberian nutrisi dan pola konsumsi makanan mempunyai dampak jangka panjang terhadap risiko terjadinya obesitas di kemudian hari, juga diabetes melitus tipe 2, hipertensi dan gangguan kardiovaskular. ${ }^{5,6}$
Makanan yang terbaik untuk bayi usia 0-6 bulan adalah ASI. Air Susu Ibu (ASI) merupakan sumber energi terbaik dan paling ideal dengan komposisi yang seimbang sesuai dengan kebutuhan bayi pada masa pertumbuhan. Pemberian ASI ini diberikan sampai bayi berusia 6 bulan, setelah 6 bulan pemberian ASI saja tidak cukup untuk memenuhi seluruh kebutuhan makanan bayi, ASI hanya akan memenuhi sekitar 60-70\% kebutuhan bayi, sedangkan $30-40 \%$ harus dipenuhi dari makanan pendamping atau makanan tambahan. ASI masih tetap diberikan hingga bayi berusia 2 tahun. ${ }^{7}$ Penelitian oleh Rahmawati $^{8}$ menggambarkan jenis MP-ASI yang paling banyak diberikan di wilayah kerja Puskesmas Pesanggrahan Jakarta Selatan antara lain pisang 25,6\%, madu 9,3\%, bubur $23,3 \%$, susu formula $11,6 \%$, pisang dan bubur $18,6 \%$, susu formula dan bubur $7 \%$, pisang dan susu formula $2,3 \%$, dan buah-buahan $2,3 \%$. Hasil penelitian serupa dilaporkan oleh Irawati (2004) dimana jenis makanan pendamping ASI yang sering diberikan adalah pisang, susu formula (bubuk dan kental manis), biskuit, bubur beras, makanan bayi produk industri dan nasi lumat. ${ }^{8}$

Penelitian ini bertujuan untuk mendapatkan gambaran pemberian MPASI di Desa Mopusi, Kecamatan Lolayan, Kabupaten Bolaang Mongondow Induk.

\section{METODE PENELITIAN}

Jenis penelitian ini ialah deskriptif dengan desain potong lintang. Pengambilan data dilakukan menggunakan kuesioner. Responden ialah ibu yang memiliki bayi usia 6-24 bulan sebanyak 90 orang di Desa Mopusi pada bulan September 2014Desember 2014. Data kemudian dianalisis dengan SPSS.

\section{HASIL PENELITIAN}

Berdasarkan hasil penelitian yang dilakukan didapatkan karakteristik sampel yang terdiri dari jenis kelamin, usia batita, usia ibu, pekerjaan ibu, pendididkan ibu, penghasilan rata- rata ibu, dan jenis MPASI. Pada Tabel 1 didapatkan batita 
berjenis kelamin laki-laki sebanyak 38 orang $(42,2 \%)$ dan perempuan 52 orang $(57,8 \%)$.

Tabel 1. Distribusi sampel berdasarkan jenis kelamin

\begin{tabular}{lcc}
\hline Jenis kelamin & Frekuensi & \% \\
\hline Laki-laki & 38 & 42,2 \\
Perempuan & 52 & 57,8 \\
Total & 90 & 100,0 \\
\hline
\end{tabular}

Tabel 2 menunjukkan distribusi batita berdasarkan kelompok usia 12-19 bulan sebanyak 42 anak (46,7\%), 20-28 bulan 36 anak $(40,0 \%)$ dan 29-36 bulan 12 anak $(13,3 \%)$.

Tabel 2. Distribusi sampel berdasarkan kelompok usia

\begin{tabular}{lcc}
\hline Kelompok usia & Frekuensi & \% \\
\hline 6-12 bulan & 42 & 46,7 \\
13-18 bulan & 36 & 40,0 \\
19-24 bulan & 12 & 13,3 \\
Total & 90 & 100,0 \\
\hline
\end{tabular}

Pada Tabel 3 terdapat distribusi usia responden $15-25$ tahun sejumlah 64 orang (71,0\%), 26-35 tahun 25 orang $(27,8 \%)$, dan $>35$ tahun 1 orang $(1,1 \%)$.

Tabel 3. Distribusi usia responden

\begin{tabular}{lcc}
\hline \multicolumn{1}{c}{ Usia } & Frekuensi & \% \\
\hline 15-25 tahun & 64 & 71,0 \\
26-35 tahun & 25 & 27,8 \\
$>35$ tahun & 1 & 1,1 \\
Total & 90 & 100,0 \\
\hline
\end{tabular}

Tabel 4 memperlihatkan distribusi pendidikan responden dimana perguruan tinggi sebanyak 3 orang (3,3\%), SD 37 orang $(41,1 \%)$, SMP 16 orang $(17,8 \%)$, dan SMA 34 orang $(37,8 \%)$.

Tabel 4. Distribusi pendidikan responden

\begin{tabular}{lcc}
\hline Pendidikan & Frekuensi & \% \\
\hline Perguruan tinggi & 3 & 3,3 \\
SD & 37 & 41,1 \\
SMP & 16 & 17,8 \\
SMA & 34 & 37,8 \\
Total & 90 & 100,0 \\
\hline
\end{tabular}

Tabel 5 menjelaskan mengenai distribusi pekerjaan responden dimana ibu yang bekerja sebagai ibu rumah tangga (IRT) sebanyak 78 orang (86,7\%), mahasiswi 2 orang (2,2\%), pedagang 3 orang $(3,3 \%)$, perawat 1 orang $(1,1 \%)$, dan petani 4 orang $(4,4 \%)$.

Tabel 5. Distribusi pekerjaan responden

\begin{tabular}{lcc}
\hline Pekerjaan & Frekuensi & \% \\
\hline IRT & 78 & 86,7 \\
Mahasiswi & 2 & 2,2 \\
Pedagang & 3 & 3,3 \\
Perawat & 1 & 1,1 \\
Petani & 4 & 4,4 \\
Total & 90 & 100,0 \\
\hline
\end{tabular}

Tabel 6 berisi informasi mengenai ratarata penghasilan ibu, yaitu: tidak ada penghasilan 76 orang $(84,4 \%)$; <1 juta perbulan 8 orang $(8,9 \%)$; $<1-3$ juta 5 orang $(5,6 \%)$; dan $>3$ juta 1 orang $(1,1 \%)$.

Tabel 6. Distribusi penghasilan responden

\begin{tabular}{lcc}
\hline Penghasilan & Frekuensi & $\mathbf{\%}$ \\
\hline Tidak ada & 76 & 84,4 \\
$<1$ juta & 8 & 8,9 \\
1 - 3 juta & 5 & 5,6 \\
$>3$ juta & 1 & 1,1 \\
Total & 90 & 100,0 \\
\hline
\end{tabular}

Tabel 7 memperlihatkan bahwa MPASI yang paling sering dikonsumsi ialah MP-ASI lokal yaitu sebesar 58 anak $(64,4 \%)$ diikuti oleh MP-ASI pabarikan sebesar 32 anak $(35,6 \%)$.

Tabel 7. Distribusi jenis MP-ASI

\begin{tabular}{lcc}
\hline Jenis MP-ASI & Frekuensi & \% \\
\hline Pabrikan & 32 & 35,6 \\
Lokal & 58 & 64,4 \\
Total & 90 & 100,0 \\
\hline
\end{tabular}

Tabel 8 memperlihatkan dari jenis MPASI pabrikan yang paling sering dikonsumsi yaitu susu formula 12 anak $(37,5 \%)$, bubur Sun 5 anak (15,6\%), biskuit 8 anak $(25,0 \%)$ dan mi instan 7 anak $(21,9 \%)$.

Tabel 9 memperlihatkan jenis MP-ASI lokal yang dikonsumsi terbanyak ialah nasi 
15 anak $(25,9 \%)$, buah 10 anak $(17,2 \%)$, telur 9 anak $(15,5 \%)$, ikan 8 anak $(13,8 \%)$, sayur 6 anak $(10,3 \%)$, tempe 5 anak $(8,6 \%)$, bubur beras 3 anak $(5,2 \%)$, dan daging 2 anak $(3,4 \%)$.

Tabel 8. Distribusi MP-ASI pabrikan

\begin{tabular}{lcc}
\hline $\begin{array}{l}\text { Jenis MP-ASI } \\
\text { pabrikan }\end{array}$ & Frekuensi & \% \\
\hline Susu formula & 12 & 37,5 \\
Bubur Sun & 5 & 15,6 \\
Biskuit & 8 & 25,0 \\
Mi instan & 7 & 21,9 \\
Total & 32 & 100,0 \\
\hline
\end{tabular}

Tabel 9. Distribusi MP-ASI lokal

\begin{tabular}{lcc}
\hline Jenis MP-ASI lokal & Frekuensi & \% \\
\hline Bubur beras & 3 & 5,2 \\
Nasi & 15 & 25,9 \\
Ikan & 8 & 13,8 \\
Sayur & 6 & 10,3 \\
Buah & 10 & 17,2 \\
Tempe & 5 & 8,6 \\
Telur & 9 & 15,5 \\
Daging & 2 & 3,4 \\
Total & 58 & 100,0 \\
\hline
\end{tabular}

\section{BAHASAN}

Air susu ibu (ASI) merupakan sumber energi terbaik dan paling ideal dengan komposisi yang seimbang sesuai dengan kebutuhan bayi pada masa pertumbuhan. Manfaat pemberian ASI tidak hanya dirasakan oleh bayi tetapi juga oleh ibu, lingkungan, bahkan negara. ASI ialah makanan yang ideal untuk bayi sehingga pemberian ASI eksklusif dianjurkan selama masih mencukupi kebutuhan bayi. ${ }^{3,9}$

Pemberian ASI ini diberikan sampai bayi berusia 6 bulan setelah itu bayi harus mulai diperkenalkan dengan makanan padat, dan ASI masih tetap diberikan hingga bayi berusia 2 tahun. ${ }^{1}$ Pada usia 6 bulan kebutuhan bayi akan zat gizi makin bertambah seiring dengan pertumbuhan dan perkembangan bayi sedangkan produksi ASI mulai menurun sehingga bayi sangat memerlukan makanan tambahan sebagai pendamping ASI. ${ }^{10,11}$

Makanan pendamping ASI ialah makanan atau minuman tambahan yang mengandung zat gizi, yang diberikan kepada bayi atau anak usia 6-24 untuk memenuhi kebutuhan gizi selain dari $\mathrm{ASI}^{3}{ }^{3}$ Pada umumnya, setelah usia 6 bulan, kebutuhan nutrisi bayi baik makronutrien maupun mikronutrien tidak dapat terpenuhi hanya oleh ASI. Selain itu, keterampilan makan (oromotor skills) terus berkembang dan bayi mulai memperlihatkan minat akan makanan lain selain susu (ASI atau susu formula). ${ }^{7,9}$

Memulai pemberian MP-ASI pada saat yang tepat akan sangat bermanfaat bagi pemenuhan kebutuhan nutrisi dan tumbuh kembang bayi. Periode ini dikenal pula sebagai masa penyapihan (weaning) yang merupakan suatu proses dimulainya pemberian makanan khusus selain ASI secara bertahap dalam jenis, jumlah, frekuensi maupun tekstur dan konsistensi sampai seluruh kebutuhan nutrisi anak terpenuhi oleh makanan. Masa peralihan ini yang berlangsung antara 6 bulan sampai 23 bulan merupakan masa rawan pertumbuhan anak karena bila tidak diberi makanan yang tepat, baik kualitas maupun kuantitasnya, dapat terjadi malnutrisi. ${ }^{7}$

Secara fisik bayi akan menunjukkan tanda-tanda siap untuk menerima makanan selain ASI yaitu antara lain refleks ekstrusi (menjulurkan lidah) telah sangat berkurang atau sudah menghilang, mampu menahan kepala tetap tegak, dan duduk tanpa/hanya dengan sedikit bantuan dan mampu menjaga keseimbangan badan ketika tangannya meraih benda di dekatnya. Secara psikologis, bayi akan memperlihatkan perilaku makan lanjutan yaitu dari reflektif ke imitatif, lebih mandiri, dan eksploratif, dan pada usia enam bulan bayi mampu menunjukkan keinginan makan dengan cara membuka mulutnya, rasa lapar dengan memajukan tubuhnya ke depan/ke arah makanan, serta tidak beminat atau kenyang dengan menarik tubuh ke belakang/menjauh. ${ }^{7}$

Semakin meningkatnya perhatian terhadap pemberian makanan pendamping yang bukan hanya terhadap apa yang dimakan, tetapi juga bagaimana, kapan, dimana dan oleh siapa anak itu diberi 
makan. Penelitian tentang perilaku makan menjelaskan bahwa jarang dilakukan tentang cara pemberian makanan; yang diamati hanyalah bila terjadi penolakan makanan oleh anak. Seharusnya perhatian lebih pada gaya dan cara pemberian makanan yang dapat meningkatkan konsumsi makanan oleh anak. ${ }^{9}$

Tabel 3, 4, dan 5 memuat informasi mengenai karakteristik responden yang merupakan ibu dari bayi 6-24 bulan yang menjadi sampel. Berdasarkan tingkat pendidikan responden didapatkan yang terbanyak ialah SD 37 orang $(41,1 \%)$ dan yang paling sedikit ialah perguruan tinggi yaitu 3 orang $(3,3 \%)$. Berdasarkan pekerjaan ibu, yang bekerja sebagai ibu rumah tangga (IRT) sebanyak 78 orang $(86,7 \%)$. Menurut penelitian sebelumnya, didapatkan tingkat ekonomi dan pendidikan ibu berpengaruh terhadap pemberian MPASI dimana pada tingkat ekonomi maupun pendidikan yang rendah, ibu cenderung memberikan MP-ASI dini dan kualitas serta kuantitas yang diberikan umumnya tidak sesuai sehingga memperburuk status gizi bayi dalam pertumbuhan. ${ }^{12-14}$

Penelitian pada populasi anak tentang pola pemberian ASI, waktu pemberian makanan tambahan, kualitas makanan dan perilaku makan aktif, berkorelasi positif dengan status antropometri anak pada orang tua dengan pendidikan rendah. Beberapa penelitian tentang intervensi perilaku merupakan bagian yang direkomendasikan yang telah didapatkan berhubungan positif terhadap efek pertumbuhan anak. ${ }^{9}$

Tujuan MP-ASI untuk menambah energi dan zat gizi yang diperlukan bayi karena ASI tidak dapat memenuhi kebutuhan bayi secara terus menerus. Makanan tambahan bayi sebaiknya memiliki beberapa kriteria antara lain, memiliki nilai energi dan kandungan protein yang tinggi, memiliki nilai suplementasi yang baik serta mengandung vitamin dan mineral yang cocok, dan dapat diterima oleh pencernaan yang baik. MPASI yang baik terbuat dari bahan makanan segar seperti tempe, kacang-kacangan, telur ayam, hati ayam, ikan, sayur, buahbuahan. $^{3}$

Pada Tabel 7 didapatkan bahwa MPASI yang paling sering dikonsumsi ialah MP-ASI lokal yaitu sebesar 58 orang $(64,4 \%)$ diikuti oleh MP-ASI pabrikan sebesar 32 orang $(35,6 \%)$. Hasil yang didapatkan ini sesuai dengan penelitian sebelumnya dimana MP-ASI lokal lebih banyak dikonsumsi dibandingkan MP-ASI pabrikan, namun seperti yang telah dibahas pada tinjauan pustaka, terdapat kekurangan pada MP-ASI lokal yaitu kadar gizi yang tidak terukur secara jelas, Walaupun dalam KMS telah tercantum cara pembuatan MPASI yang bergizi baik akan tetapi terkadang ibu rumah tangga tidak terlalu memperhatikan hal tersebut sehingga nantinya konsumsi MP-ASI lokal tidak terukur secara jelas kadar gizinya dan dapat memengaruhi perkembangan anak karena ketidaksesuaian antara asupan gizi dan kebutuhan gizi yang dibutuhkan oleh anak. ${ }^{3}$

Tabel 8 memuat informasi jenis MPASI pabrikan yang paling sering dikonsumsi yaitu susu formula 12 orang $(37,5 \%)$, bubur sun 5 orang $(15,6 \%)$, biskuit 8 orang $(25,0 \%)$ dan mi instan 7 orang $(21,9 \%)$. Telah diketahui kelebihan pada MP-ASI pabrikan ialah kadar gizinya telah diukur oleh Departemen Kesehatan RI untuk disesuaikan terhadap kebutuhan gizi anak-anak yang mengonsumsinya. Kadar kandungan gizi yang telah terukur tersebut secara langsung akan berpengaruh terhadap perkembangan anak oleh karena zat gizi makronutrien dan mikronutrien yang terkandung di dalamnya merupakan faktor yang berpengaruh pada maturitas otak dan pembentukan jaringan-jarinan tubuh di masa keemasan tumbuh kembang anak, yaitu usia 1-3 tahun. Meskipun WHO sudah memperjelas indikasi medis pemberian susu formula bayi, tetapi kenyataannya yang terbanyak ialah masalah non-medis misalnya ibu bekerja, jarak rumah dengan tempat kerja jauh, dan fasilitas tempat untuk memerah ASI tidak tersedia. $^{7}$

Untuk jenis MP-ASI lokal yang dikonsumsi (Tabel 9) didapatkan yang 
paling banyak dikonsumsi ialah nasi 15 orang $(25,9 \%)$, buah 10 orang $(17,2 \%)$, telur 9 orang $(15,5 \%)$, ikan 8 orang $(13,8 \%)$, sayur 6 orang $(10,3 \%)$, tempe 5 orang $(8,6 \%)$, bubur beras 3 orang $(5,2 \%)$, dan daging 2 orang $(3,4 \%)$. Berdasarkan penelitian dilakukan di Kecamatan Pesanggarahan (Jakarta) didapatkan jenis MP-ASI lokal yang sering diberikan ialah pisang (buah) dan yang paling sedikit diberikan ialah sayur. Perbedaan ini dapat dipengaruhi oleh budaya atau kebiasaan setempat maupun tingkat ekonomi maupun pendidikan. $^{8}$

Mengingat nutrien yang paling tidak terpenuhi kebutuhannya setelah usia enam bulan yaitu zat besi (Fe), maka pilihan utama ialah memberikan makanan yang kaya akan zat besi. Selain itu, makanan padat pertama yang terbaik ialah yang terbuat dari beras karena beras merupakan bahan makanan yang paling hipoalergenik sehingga kemungkinan terjadinya reaksi simpang paling minim. Gandum dan campuran serealia lainnya sebaiknya ditunda hingga usia 8 bulan untuk menghindari timbulnya reaksi alergi dan masalah pencernaan. ${ }^{7,15}$

\section{SIMPULAN}

Berdasarkan penelitian yang dilakukan pada bayi di Desa Mopusi Kecamatan Lolayan Kabupaten Bolaang Mongondow Induk dapat disimpulkan bahwa MP-ASI yang sering diberikan ialah MP-ASI lokal. Jenis MP-ASI lokal yang paling banyak diberikan ialah nasi dan yang paling sedikit diberikan ialah daging. Jenis MP-ASI yang jarang diberikan ialah MP-ASI pabrikan. Jenis MP-ASI pabrikan yang paling banyak diberikan ialah susu formula dan yang paling sedikit diberikan ialah bubur Sun.

\section{SARAN}

Bagi institusi kesehatan dan pemerintah agar lebih meningkatkan penyuluhan tentang MP-ASI yang baik kepada ibu-ibu yang mempunyai anak batita yang dapat disosialisasikan melalui berbagai kegiatan diantaranya pertemuan PKK, arisan ibu-ibu, ibadah, dan lain-lain.
Bagi petugas kesehatan dan kader-kader di instansi kesehatan lebih berperan aktif untuk memberikan petunjuk yang benar tentang cara pemberian MP-ASI

\section{DAFTAR PUSTAKA}

1. UNICEF. Levels \& Trends in Child Mortality Report 2015. Estimates developed by the UN Inter-agency Group for Child Mortality Estimation. 2015.

2. Lawn JE, Cousens S, Zupan J. 4 million neonatal deaths: When? Where? Why? Lancet. 2005;365(9462):891900.2005.

3. Departemen Kesehatan RI. Pedoman Umum Pemberian Makanan Pendamping Air Susu Ibu (MP-ASI) Lokal Tahun 2006. Direktorat Jenderal Bina Kesehatan Masyarakat. 2006.

4. Badan Penelitian dan Pengembangan Kesehatan. Riset Kesehatan Dasar. Kementerian Kesehatan RI. 2013.

5. Yu P, Denney L, Zheng Y, Vinyes-Pares G, Reidy KC, Eldridge AL, et al. Food groups consumed by infants and toddlers in urban areas of China. Food Nutr Res. 2016;60:1-12.

6. Fitriana EI, Anzar J, Nazir HM, Theodorus. Dampak Usia Pertama Pemberian Makanan Pendamping Asi Terhadap Status Gizi Bayi Usia 8-12 Bulan di Kecamatan Seberang Ulu I Palembang. Sari Pediatri. 2013; 15(4): 249-53.

7. UKK Nutrisi dan Penyakit Metabolik IDAI. Rekomendasi Praktik Pemberian Makan Berbasis Bukti pada Bayi dan Batita di Indonesia untuk Mencegah Malnutrisi. Rekomendasi IDAI. 2015.

8. Rahmawati R. Gambaran Pemberian MPASI pada bayi kurang dari 6 bulan di Wilayah Kerja Puskesmas Kecamatan Pesanggrahan Jakarta Selatan tahun 2014. Skripsi. 2014.

9. Dewey K, Lutter C. Guiding Principles for Complementary Feeding of the Breastfed Child. Pan American Health Organization, World Health Organization, Divison of Health Promotion and Protection, Food and Nutrition Program. 2001.

10.WHO. Infant and young child feeding. Model Chapter for textbooks for medical students and allied health 
professionals. 2009.

11.WHO. Complementary Feeding Family foods for breast aged children. Department of Nutrition for Health and Development. 2000.

12.Turnip F. Pengaruh "Positive Deviance" pada Ibu Dari Keluarga Miskin Terhadap Status Gizi Anak Usia 1224 Bulan di Kecamatan Sidikalang Kabupaten Dairi Tahun 2007. USU Repository [Tesis]. 2008.

13.Rao S, Swathi PM, Unnikrishnan B, Hegde A. Study of complementary feeding practices among mothers of children aged six months to two years
- A study from coastal South India. Australas Med J. 2011; 4(5):252-257.

14.Ibrahim M, Rattu AJM, Pangemanan JN. Hubungan antara karakteristik ibu dan perilaku ibu dengan riwayat pemberian makanan pendamping ASI (MP-ASI) dini di wilayah Puskemas Atinggola Kecamatan Atinggola Kabupaten Gorontalo Utara Tahun 2014. JIKMU. 2015;5(2).

15.Nasar SS. Makanan pendamping ASI (MPASI). [Online]. 2013. Available from: http://www.idai. or.id/artikel/ klinik/asi/makanan-pendamping-asimpasi.] 